\title{
NATIONAL AND CULTURAL FEATURES OF JAPANESE LANGUAGE PHRASEOLOGISMS
}

\author{
Nargiza Akhmedovna Turapova
}

Phd, Teacher, Tashkent State University Of Oriental Studies, Uzbekistan

\section{ABSTRACT}

Phraseologisms are characteristic of all languages of the world, but they have their own special forms of expression. They reflect character traits, worldview, lifestyle of representatives of a particular people. Phraseologisms of any language, being associated with the geographical conditions of the country, historical development, state system and religion, are not always clear. In the Japanese language, there are many phraseological units that are not translated verbatim, but are perceived rethought and enhance the aesthetic aspect of the language.

The article deals with several thematic groups of Japanese phraseological units, which include the names of historical events, household items, the names of games, animals, which are included in the basic vocabulary of the language and reflect the processes characteristic of the language and its national specifics, and we can say that the overwhelming majority Japanese phraseological units reflect the mentality of the nation, originality, worldview of peoples - native speakers, i.e. phraseological units contain a cultural connotation that reflects the everyday empirical, historical, spiritual experience of the Japanese people.

KEYWORDS: - Phraseological units, culture of the people, national characteristics, cultural semantics.

\section{INTRODUCTION}

Any language expresses the culture of the people who speak it. Learning a foreign language always means also getting to know the new culture that underlies the given language. V.N. Telia writes that "the phraseological composition of the language is a mirror in which the linguocultural community identifies its national identity. It is the phraseological units that the native speakers call a special vision of the world, of the situation" $(4,284)$. Phraseologisms are common to all languages of the world, but they have their own special forms of expression. They reflect character traits, worldview, lifestyle of representatives of a particular people. Phraseologisms of any language, being associated with the geographical conditions of the country, historical development, state system and religion, are not always clear. In the Japanese language, there are many phraseological units that are not translated verbatim, but are perceived rethought and enhance the aesthetic aspect of the language.

Phraseologisms are one of the most interesting manifestations of the nationally determined specificity of the mentality of the people. According to V.A. Maslova, "the inner form of most phraseological units contains such meanings that 
CURRENT RESEARCH JOURNAL OF PHILOLOGICAL SCIENCES 2(12):

177-182, December 2021

DOI: https://doi.org/10.37547/philological-crjps-02-12-34

ISSN 2767-3758

(C)2021 Master Journals

Crossref do

gil Google

Accepted21 ${ }^{\text {th }}$ December, 2021 \& Published $26^{\text {th }}$ December, 2021

give them a cultural and national flavor" $(3,82-86$.$) .$ National and cultural characteristics have a great influence on the formation of the language.

The presence of cultural semantics in phraseological units predetermines the "longevity" of phraseological units in a living language, since phraseological units are reproduced by a native speaker not only in their direct, linguistic function nominative, but also in the cultural function.

It should be noted that over the centuries Japanese phraseology has evolved under the influence of a wide range of social, economic, political, cultural and environmental factors. The countries of the Great Silk Road, namely China, as well as Buddhism, had a particular influence on the development of the Japanese phraseological fund before the Meiji revolution of 1868, and since the middle of the 19th century. Western trends and scientific achievements have a significant impact on traditional Japanese culture and language.

\section{Methods}

In this article, we will cite several thematic groups of Japanese phraseological units, which include the names of historical events, household items, names of games, animals, which are included in the basic vocabulary of the language and reflect the processes characteristic of the language and its national specifics.

History. Phraseologisms that carry the names of historical characters and places in their vocabulary: いざ鎌倉 idza kamakura (literally. so to Kamakura!) - at a critical moment, this phraseological unit originates from the Kamakura era (1192-1333), when there was a rule according to which when any important events happened, it was necessary to urgently go to the city of Kamakura, where a military-feudal headquarters "bakufu" located at that time to solve a problem; with the name of the historical era of Tempo, dated from 1830 to 1844 . the phraseological unit 天保時代の人tempodzitaino hito (literally people of the Tempo era) - people of the old school, also used 天保の時代 tempo-no dzitai - old times; The next phraseological unit originates from conversations that were conducted near the Edo castle by visiting officials about their secret affairs 下馬評 gebahyo: - rumors, gossi; 関ヶ原 sekigahara - decisive battle - from the name of the place of the historical battle in 1600 before the establishment of the Tokugawa era; 小田原評所 odawara-hyojo - empty words. This phraseological unit originates from the event of 1591, when peace negotiations between Toyotomi Hideyoshi and his opponents dragged on for a long time in the Odawara castle, the negotiations ultimately did not lead to anything; the phraseological unit is associated with the historical character 弁慶の泣き所 benkei-no nakidokoro (literally Benkei's ston), despite the fact that he was a famous warrior and strongman, Benkei still had weaknesses, hence the name of the phraseological unit "Benkei's groan" that means smb.'s weak point; the name of the historical place in Kyoto Kiyomizu, where the temple is located, with a high-located wide platform, is associated with the phraseological unit 清水の舞台から飛び降りる kiyomidzu-no butai-kara tobioriru (literally, to jump off the stage of Kiyomizu), meaning "to take a desperate step".

Calligraphy, language, literature. In 774-835, the famous Buddhist figure, calligrapher Kobo lived and he could write brilliantly with any brush, the phraseologism 弘法は筆を選ばず is associated with his name Kōbōha fudewo erabazu (lit., kobo does not choose the brush) - the scythe is to blame for the bad mower; 書を校するのはちりを掃うがごとしSho o kō suru no wa chiri-o harau-ga go to shi (literally to engage in the art of calligraphy is to constantly sweep away 
CURRENT RESEARCH JOURNAL OF PHILOLOGICAL SCIENCES 2(12):

177-182, December 2021

DOI: https://doi.org/10.37547/philological-crjps-02-12-34

ISSN 2767-3758

(C2021 Master Journals

Crossref do

81 Google

Accepted21 ${ }^{\text {th }}$ December, 2021 \& Published $26^{\text {th }}$ December, 2021

the dust) - it is difficult to achieve complete perfection in calligraphy, i.e. you need to constantly improve;

ふるなの弁 Furu na no ben (literally, Purna's eloquence) - brilliant eloquence, this phraseological unit is associated with the name of Purna - one of the 10 disciples of Buddha, distinguished by the refinement of speech; phraseological unit associated with literature 文は武に優る bun wa bu ni masaru - the feather of a powerful sword.

Religion. Most phraseological units are associated with the name of Buddha, Buddhism and Shinto:

\section{三人寄れば文殊の知惠San'nin' yoreba} monjunochie (literally, three will gather - that's the wisdom of Mondju himself - mind is good - two is better, one head is good, two is even better; 釈迦に説法 Shakani seppō: (literally, the sermon of Shakyamuni (Buddha)) - to teach the scientist only to spoil; 地獄で仏に会ったよう Jigokude hotoken iattayō: (literally, as if he met Buddha in hell) - to be saved in a difficult situation, a friend in trouble.

There are phraseological units with the mention of a trait: 鬼に金棒 onini kanabō: (lit. to give the devil an iron stick) - to strengthen the power of one who is already strong; 鬼の目にもなみだoni no me ni mo namida (literally, there are tears even in the eyes of the devil) - even the devil will cry; 鬼の留守に洗濯oni no rusu ni sentaku (lit. wash in the absence of devils) - when there is no cat, the mice have plenty of freedom.

Further follow phraseological units associated with belief in omens, superstition of the Japanese: 縁起をかつぐengi o katsugu (lit. carry omens) - to believe in omens, to be superstitious; ごへいを担ぐgo e i o katsugu (lit. carry gohei) - to be superstitious, to believe in omens. In this example, gohei are paper sticks used in Shinto shrines.

Folklore, traditions and customs. There are phraseological units that arose from legends, as well as folklore and elements of the customs of the Japanese people.

開けて悔しい玉手箱akete kuyashī tamatebako everything turned out to be useless, in the end nothing came of it. According to legend, the hero Urashima, having returned from the seabed, contrary to the prohibition, opened the sea princess's casket presented to him and immediately aged by 300 years; in Japanese fairy tales there is a fantastic creature kappa - a vampire that looks like a child, the face of a tiger cub and a hollow on the crown. The kappa lives in water and on land, lures its victims into the water and drowns them. Good swimmers are often called kappa. 河童の屁каппано хэ (literally real water) - knee-deep sea, just spit; phraseologism 成功の彼岸に達す seikō no higan ni tassu - to achieve success is associated with the week of the equinox Higan; はちまきをするhachimaki o suru (roll up hachimaki) - roll up your sleeves. Hachimaki is a scarf tied with a tourniquet around the head so that sweat from the forehead does not drip into the eyes during work. This expression means willingness to work or to fight.

Sports, arts, games. Fundoshi is a loincloth for a sumo wrestler (a type of Japanese wrestling), this thing is purely personal, taking someone else's fundoshi means "using the thing for other people's purposes, raking in the heat with someone else's hands": 人のふんどうしで相撲をとる hito no fundōshi de sumou o toru (lit. to wrestle sumo in someone else's fundoshi); 芸は身につくgei wa mi nitsu - talent cannot be taken away; 碁に負けたら将棋に勝て go ni maketara shōgi ni kate (lit. if you lost in go, win in shōgi) - if you see 
CURRENT RESEARCH JOURNAL OF PHILOLOGICAL SCIENCES 2(12):

177-182, December 2021

DOI: https://doi.org/10.37547/philological-crjps-02-12-34

ISSN 2767-3758

(C)2021 Master Journals

Crossref do

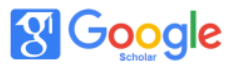

Accepted21 ${ }^{\text {th }}$ December, 2021 \& Published $26^{\text {th }}$ December, 2021

that something is failing somewhere, go to where you can achieve success. Go is a Japanese game of checkers type, shōgi is Japanese chess.

Garments. In Japanese, we mentioned the following among the names of national clothes: geta, waraji, fundoshi, kamishimo, hakama, tamoto. For the Japanese people, geta-wooden shoes and waraji straw sandals symbolize movement, train anywhere: げたをあずける гэта-о адзукэру ((lit. to deposit geta) - to disclaim all responsibility, わらじをはく waraji o haku (lit. to dress waraji) to go on a trip, 二足のわらじを履く nisokunowarajiwohaku (lit. to wear two pairs of waraji) - about combining two incompatible affairs in the pursuit of profit; Samurai of the Edo era wore a ceremonial kamishimo costume at official meetings, while taking off this costume, a person will behave at ease, without much ceremony: 裃を脱ぐkamishimowonugu (letters. shoot kamishimo) - behave unceremoniously, at ease; while working in a dye shop, wearing a hakama (clothing in the form of a skirt, worn over a kimono and fitting a figure from the waist down) over a kimono, she was always the same color, since the dyer would not have time to dye it, hence the phraseological unit 紺屋の白袴 kōyanoshirobakama (lit. white dyer hakama). This expression is equivalent to the Russian expression "shoemaker without boots" (in English: the shoemaker's son always goes barefoot).

In the case of separation, interrupting a relationship with smb., it is enough to cut off the lower part of the kimono 袂を分かつ tamotowowakatsu (lit. to divide tamoto) where tamoto is the lower part of the kimono sleeve (bag-shaped).

Food. In the old times in Japan, sellers of oils entered every home and sold it by pouring it through a funnel. The process itself was slow, and while the oil was being poured, they were discussing the latest news or just chatting. Hence the phraseological unit 油を売る abura o uru (lit. to sell oil) - to chat; in the meaning of "to get out of the position" in Japanese, the phraseological unit お茶をにごす ocha o nigosu (lit. muddy the tea) is used, the following phraseological unit is associated with the traditional Japanese drink made from rice sake: 酒は百薬の長sake wa Hyakuyakunochō: (sake - a cure for hundreds of diseases) - to know when to stop; personally prepared soybean paste miso, gives a reason to boast 手前味噌 temae miso (miso of its own production) - bragging, boasting, being the staple food of the Japanese - rice, the concept of "prosperity, satisfaction" is associated with it: 飯の種 meshi-no tane (boiled rice seed) source of income, livelihood if you want mochi Japanese rice cakes - then contact a mochi, as he is an expert in his field: 餅は餅屋 mochihamochiya (mochi - to mochiya) - entrust the matter to a master, a professional, 人をだしに使う hito-o dashini tsukau (lit. use a person as a dashi) - use someone as a figurehead. In this phraseological unit, the word dashi is used, which is a broth or soup in Japanese cooking, serving as a seasoning sauce.

Japanese household items. 同じかまの飯を食う onaji kama no meshi o kuu (lit. eat from one pot) - to live with smb. under the same roof, to be on good terms with smb.; くぎをさす kugi-o sasu (to stick a nail) - to remind of smth.; 固めのさかずきを交わす katame-no sakazuki-o mawasu (exchange sakazuki) - to take a vow of loyalty to a spouse or partners; さじをなげるsaji-o nageru (to throw a spoon) - to despair, to lose hope; 障子にも耳あり shoji-nimo mimi ari (shoji has ears) - and the walls have ears; 箸にも棒にもかからない hasi-nimo bo: -nimo kakaranai (no chopsticks work, no club) - hopeless, incorrigible; まないたの鯉(こい)manaita-no koi (carp on a cutting board) - to be in a helpless state, 
CURRENT RESEARCH JOURNAL OF PHILOLOGICAL SCIENCES 2(12):

177-182, December 2021

DOI: https://doi.org/10.37547/philological-crjps-02-12-34

ISSN 2767-3758

(C)2021 Master Journals

Crossref dof 81 Google

Accepted21 ${ }^{\text {th }}$ December, 2021 \& Published $26^{\text {th }}$ December, 2021

to be left to fend for themselves.

These examples contain vocabulary from the names of objects inherent in Japanese life: hasi - Japanese chopsticks, koi - a type of carp, kama - a Japanese pot, sakazuki - a small bowl for the traditional alcoholic drink sake, shoji - sliding partitions in a Japanese house, etc.

Animals. According to T.M. Gurevich "The Japanese very often, much more often than the Russians, compare humans with representatives of the fauna. It should be noted that the Japanese not only see and evaluate the behavior and character of various animals differently than we do, but, comparing humans with them, significantly expand their list, including marine life " $(1,47)$. The habits and lifestyle of birds and fish, animals and insects cause quite definite associations with the appearance and behavior of humans.

In Japanese linguoculture, there is the use of phraseological units with the names of animals inherent in Japan, it can be a fox, tanuki (raccoon dog), monkey, cat, crane, eel fish, snake. Unagi eel fish is considered in Japan to be a very fast and mobile fish, sea bass tai is considered a valuable commercial fish, therefore the Japanese love and appreciate it very much, and put it in first place among other fish:

うなぎ登り unagi no nobori (lifting an eel) - steadily rise, rise; えびでたいを釣る ebi-de tai-o tsuru (to catch sea bass with a shrimp) - sacrifice small for the sake of more; 腐ってもたい kusatte mo tai (although rotten, but perch); いわしの頭となるよりはたいの尾につけ atama to naru yori wa tai no o ni tsuke (better to be the tail of a perch than head of iwashi).

A fox - kitsune, and a raccoon dog - tanuki, are considered negative characters in Japanese linguistic culture they, phraseological units with them often have a negative connotation: きつねにつままれる kitsune-ni tsukamareru (to be captured by a fox) - to be confused, confused bewilderment; きつねとためきの化かし合い kitsune-to-tanuki-no bakashiai (mutual deception of the fox and tanuki) - lead each other by the nose. In Russian and Uzbek, speaking about bad relations between someone they say "koshka s sobakoy" (Russian), "it mushukdek" (Uzbek), in Japanese they say: 犬猿の仲 kenen-no naka (relationship like a dog with a monkey) - not getting along with each other, relationship like a cat with a dog.

In Japan, the symbolic bird is the crane, speaking of an imperious voice, they use the word "tsuru" - a crane: つるの一声 tsuru-no koe (literally the voice of the crane) - an authoritative decision, an imperious voice.

Color. The colors indicated in the phraseological units of the Japanese language are most often of three types: red, black and white.

赤子の手をひねるakako no te-o hineru (literally twisting the red child's arms) is very simple; 赤の他人 aka-no tannin (literally red stranger) - a completely outsider, a stranger; 赤玉 akadama (literally red ball) - amber;

赤着物を着せられるaka kimono o kise rareru (to make you wear a red kimono) - go to jail; 赤鬼 akaoni (literally red line) - persistent creditor; 赤とんぼakatonbo (literally red dragonfly) - enemy aircraft; 赤鰞 akaivasi (lit. red iwashi) - rusty sword; 赤字 akaji (lit. red letters) - deficit; 赤本 akahon (literally red books) - tabloid literature; 赤新聞akasinbun (literally red newspaper) - yellow press; 黒字 kuroji (literally black letters) - active balance; 黒字になる kuroji-ni naru (literally become black letters) - reduced to active balance; 
CURRENT RESEARCH JOURNAL OF PHILOLOGICAL SCIENCES 2(12):

177-182, December 2021

DOI: https://doi.org/10.37547/philological-crjps-02-12-34

ISSN 2767-3758

(C)2021 Master Journals

crossref do) :810 Google

Accepted21 ${ }^{\text {th }}$ December, 2021 \& Published $26^{\text {th }}$ December, 2021

黒星 kuroboshi (lit. black dots) - failure, defeat; 黒白をつける kuroshiro-o tsukeru (lit. attach black and white) - firmly determine what is good and what is bad; 白い歯を見せる siroi ha-o miseru (lit. to show white teeth) - to show a joyful, benevolent face; 白を切る shiro-o kiru (lit. to cut the white) pretend not to know; 黄色声 kiiro koe (literally yellow voice) - shrill voice; くちばしが黄色い kuchibashi-ga kiiroi (lit. yellow beak) - young, imperfect person.

As can be seen from the examples, the largest number of phraseological units with aka color is red, phraseological units with this color stand out for their expressiveness, and they can be considered expressive-emotional.

\section{Conclusion}

It can be concluded that the daily world of the Japanese, reflected in phraseology, is largely material. The Japanese are characterized by a special attitude to daily things, which took shape in the concept of "monoavare" - admiring the world of things. It is based on the principle of consciousness of the transience of the world of feelings and things. This concept developed during the Heian historical period (794-1185).

Thus, as can be seen from the analysis, the overwhelming majority of Japanese phraseological units reflect the mentality of the nation, originality, worldview of peoples - native speakers, i.e. phraseological units contain a cultural connotation that reflects the everyday empirical, historical, spiritual experience of the Japanese people.
Comparative linguistics. Typology of languages. Translation theory: materials of the 3rd international conference. Moscow Kazan, 2006-2008. - M.: Moscow State University, 2008.- P. 47-56.

2. Maslova V.A. Linguoculturology M., 2001, p.82 - 86

3. Maslova V.A. Literature index, p.88

4. Telia V.N. Russian phraseology M., 1996 248p.

5. Takao Suzuki. Language and culture of Tokyo 1990 - p. 209.

6. Frolova O. P. Phraseology of the modern Japanese language Novosibirsk, 1979 - pp. 45 $-49$.

\section{REFERENCES}

1. Gurevich T.M. Japanese language: the problem of translation of zoonyms. 